\title{
BADANIE WLASNOŚCI MECHANICZNYCH STALI DROBNOZIARNISTEJ DOMEX 700MC
}

\begin{abstract}
Streszczenie: W rozdziale przedstawiono wyniki badań własności mechanicznych stali drobnoziarnistej Domex 700MC. Badania prowadzone w ramach badań własności zmęczeniowych stali klasyfikowanych do aplikacji nowych materiałów w konstrukcjach naczep samochodowych. Przedstawione badania obejmują wyniki statycznej próby rozciągania oraz udarności w zakresie temperaturowej -70 do $+100^{\circ} \mathrm{C}$. Analiza badań uzupełniona została o analizę struktury materiału oraz spektrometryczną analizę składu chemicznego materiału.
\end{abstract}

Slowa kluczowe: stale drobnoziarniste, statyczna próba rozciągania, udarność Charpy'ego

\section{Wstęp - warunki podjęcia tematu badań}

Duża konkurencja na rynku motoryzacyjnym, jak również rynku budowy maszyn oraz ekspansja nowych materiałów doprowadziły koncerny stalownicze do dużej aktywności badawczej i racjonalizatorskiej. Efektem tych badań było wdrożenie nowoczesnych technologii metalurgicznych i przetwórstwa hutniczego, co doprowadziło do powstania różnych grup stali o szerokim zakresie własności mechanicznych i odkształcalności technologicznej. Mimo stosowania w elementach konstrukcyjnych samochodów, maszyn, a także naczep samochodowych stopów metali lekkich masę tych konstrukcji w 60\% stanowią elementy wykonane $\mathrm{z}$ blach stalowych o coraz większej wytrzymałości (FlaXA V., SHAW J. 2003; GRAJCAR A. 2009). Pojawienie się stosunkowo nowej grupy materiałów stawia przed konstruktorami nowe wyzwania, a optymalizacja doboru materiału konstrukcyjnego jest kluczowa dla procesów eksploatacyjnych, co skłania do prowadzenia

${ }^{1}$ dr inż., Politechnika Częstochowska, Wydział Zarządzania, Instytut Inżynierii Produkcji, e-mail: mazur.m@zim.pcz.pl 
prac badawczych dotyczących odporności materiału na warunki pracy, zwłaszcza w zakresie obciążeń zmiennych. Głównym parametrem wyznaczającym kierunki badań jest stosunek wytrzymałości do masy elementu konstrukcyjnego. Wynika to z faktu, że właśnie ta zależność w największym stopniu decyduje o zużyciu paliwa w samochodach czy też w dalszym przełożeniu o zasięgu samolotów. Producenci zainteresowani są głównie optymalizacją kosztów działalności i zwiększeniem produkcji. Zwracają więc przy tym uwagę na uzyskanie jak największej trwałości obiektu, poprzez poszukiwanie nowych rozwiązań konstrukcyjnych produkowanych wyrobów, jak również zastosowanie odpowiednich materiałów (materiałów o odpowiednich własnościach). Gwarancja jakości i bezpieczeństwa eksploatacji maszyn oraz urządzeń jest $\mathrm{w}$ tym przypadku czynnikiem determinującym zdolność aplikacyjną nowych materiałów. Działy konstrukcyjne podmiotu badawczego prowadzą prace majace na celu aplikację nowych materiałów na elementy konstrukcyjne naczep (rys. 1) w celu zmniejszenia masy własnej, zmniejszenia zużycha paliwa, zwiększenia tonażu przewożonego ładunku i wydłużenia okresu bezpiecznej eksploatacji.

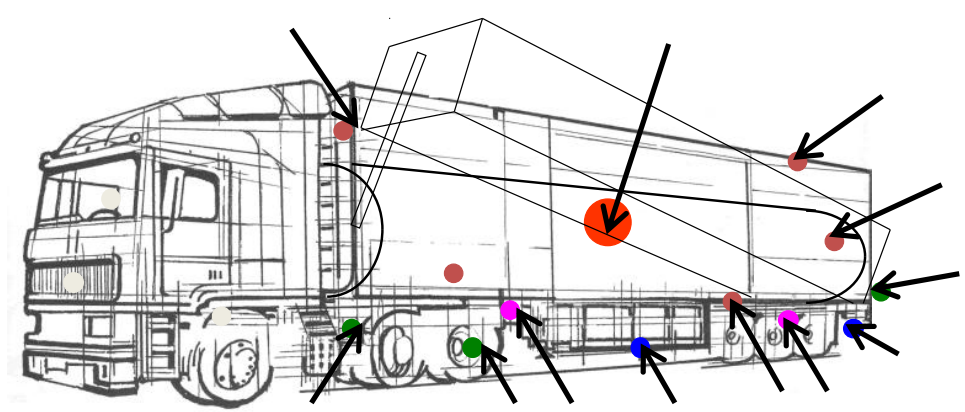

Rys. 1. Potencjal aplikacji nowych materiatów “lekkich” samochodów dostawczych

Źródło: ARMIGLIATO A. 2014 


\section{Charakterystyka materiału badawczego}

Stal Domex do kształtowania na zimno jest to stal walcowana na gorąco $\mathrm{W}$ procesie termomechanicznym, gdzie procesy grzania, walcowania i chłodzenia są dokładnie kontrolowane. Skład chemiczny tej stali, zawierającej niski poziom węgla i manganu, jest precyzyjnie uzupełniany przez składniki uszlachetniające takie jak niob, tytan czy wanad. W połączeniu z czystą strukturą sprawia to, że stal Domex jest najlepszą alternatywą dla produktów kształtowanych na zimno i spawanych. Stal Domex 700MC z oznaczeniem D i E spełnia, a nawet przewyższa wymagania dla stali S700 MC według normy EN-10149-2 (SSAB Oxelösund. 2012, MAZUR M., ULEWICZ R.: 2012].

Ekstrawysokowytrzymałe gatunki stali znajdują zastosowanie w takich konstrukcjach jak podwozia ciężarówek, elementy dźwigów czy koparek. W zastosowaniach tych wysoka wytrzymałość stali jest wykorzystywana $\mathrm{w}$ celu zmniejszenia ciężaru przy jednoczesnym zwiększeniu nośności konstrukcji. Te zalety $\mathrm{w}$ połączeniu $\mathrm{z}$ dobrą formowalnością pozwalają na obniżenie kosztów całkowitych eksploatacji. Ze względu na małą zawartość węgla, fosforu i siarki stal Domex 700MC może być spawana przy użyciu wszelkich powszechnie stosowanych metod. Nie jest także wymagane podgrzewanie wstępne. Na granicy spawu tworzy się wąska strefa wpływu ciepła o nieco mniejszej twardości. Jednak przy użyciu normalnych parametrów i metod spawania strefa ta nie ma praktycznego znaczenia. Testowane próbki wykonane w poprzek spoiny mogą wykazywać tę samą minimalną wartość wytrzymałości na rozciąganie, co materiał spawany. W przypadku gdy obciążenia spoiny nie będą duże, można stosować spoiwa o mniejszej wytrzymałości niż spawany materiał. Istnieje duża ilość spoiw o tej samej lub większej wytrzymałości, które mogą być stosowane do spawania stali Domex 700MC, przy jednoczesnym zachowaniu tej samej wytrzymałości spoiny, co spawany materiał. Tabela 2 przedstawia skład chemiczny i własności mechaniczne stali Domex 700MC. 
Tabela 1. Sktad chemiczny i wybrane wlasności stali Domex 700MC [3]

\begin{tabular}{|c|c|c|c|c|c|c|c|c|}
\hline \multicolumn{9}{|c|}{ Skład chemiczny max. [\% mas.] } \\
\hline $\mathbf{C}$ & Si & Mn & $\mathbf{P}$ & $\mathbf{S}$ & Al & $\mathbf{N b}$ & $\mathbf{V}$ & Ti \\
\hline 0,12 & 0,10 & 2,10 & 0,025 & 0,010 & 0,015 & 0,09 & 0,20 & 0,015 \\
\hline \multicolumn{9}{|c|}{ Wlasności mechaniczne } \\
\hline \multicolumn{3}{|c|}{$\mathbf{R}_{\mathrm{e}}[\mathrm{MPa}]$} & \multicolumn{3}{|c|}{$\mathbf{R}_{\mathrm{m}}[\mathrm{MPa}]$} & \multicolumn{3}{|c|}{ A5 [\%] } \\
\hline \multicolumn{3}{|c|}{700} & \multicolumn{3}{|c|}{$750 \div 950$} & \multicolumn{3}{|c|}{12} \\
\hline
\end{tabular}

Źródło: (SSAB Oxelösund, 2012)

\section{Badania}

Prace eksperymentalne skupione są na doświadczalnym badaniu trwałości zmęczeniowej zakwalifikowanych do badań stali drobnoziarnistych uzupełnione zostały badaniami własności mechanicznych, mających na celu porównanie wyników testów $\mathrm{z}$ informacjami producenta. Do pełnej charakterystyki własności zmęczeniowych materiałów główne badania uzupełnione zostały o analizę składu chemicznego, statyczną próbę rozciągania oraz analizę struktur stali. Badania metalograficzne przeprowadzono z zastosowaniem mikroskopii świetlnej. Elementy konstrukcji w czasie pracy narażone są bardzo często na obciążenia dynamiczne. Dlatego też dla poznania własności charakteryzujących zachowanie się materiału w przypadku wystąpienia nagłych zmian obciążenia przeprowadzone zostały również badania udarności. Ze względu na zastosowanie materiału w elementach konstrukcyjnych naczep samochodowych użytkowanych w skrajnych warunkach temperaturowych próby wykonane zostały z uwzględnieniem tego właśnie czynnika.

Analizy składów chemicznych wykonano metodą spektometrii emisyjnej, skład chemiczny analizowanych materiałów przedstawia tablica 2. 
Tab. 6. Wyniki analizy sktadu chemicznego badanych materiatów

\begin{tabular}{|c|c|c|c|c|c|c|c|c|}
\hline \multicolumn{9}{|c|}{ Zawartość procentowa pierwiastków [\%] } \\
\hline \multicolumn{9}{|c|}{ stal wysokowytrzymała - Domex 700MC } \\
\hline $\mathrm{C}$ & $\mathrm{Si}$ & $\mathrm{Mn}$ & $\mathrm{P}$ & $\mathrm{S}$ & $\mathrm{Al}$ & $\mathrm{Nb}$ & $\mathrm{V}$ & $\mathrm{Ti}$ \\
\hline 0,08 & 0,35 & 1,67 & 0,018 & 0,0037 & 0,015 & 0,06 & 0,014 & 0,015 \\
\hline \multicolumn{2}{|c|}{$\begin{array}{c}\mathbf{R e} \\
{[\mathrm{MPa}]}\end{array}$} & \multicolumn{3}{|c|}{$\begin{array}{c}\mathbf{R m} \\
{[\mathrm{MPa}]}\end{array}$} & \multicolumn{2}{|l|}{$\begin{array}{c}A_{5} \\
{[\%]}\end{array}$} & \multicolumn{2}{|c|}{$\begin{array}{c}\mathrm{Z} \\
{[\%]}\end{array}$} \\
\hline \multicolumn{2}{|c|}{796} & \multicolumn{3}{|c|}{850} & \multicolumn{2}{|l|}{15,5} & \multicolumn{2}{|c|}{36,1} \\
\hline
\end{tabular}

Źródło: opracowanie własne

Wyniki analizy składu chemicznego porównano z danymi producenta stali wysokowytrzymałych (tablice 1 i 2 ). Analiza porównawcza składu chemicznego potwierdza, że zawartość pierwiastków chemicznych odpowiada parametrom przewidzianym przez producenta $\mathrm{w}$ karcie materiałowej.

W celu określenia podstawowych właściwości wytrzymałościowych analizowany materiał (granica plastyczności $R_{e}$, wytrzymałości na rozciąganie $R_{m}$, wydłużenia $A_{5}$ i przewężenie $Z$ ) wykonana została statyczna próba rozciągania. Próby te przeprowadzono w laboratorium zmęczeniowym Uniwersytetu Żylińskiego na zrywarce Zwick Z050 w temperaturze otoczenia $T=20^{\circ} \mathrm{C} \pm 10^{\circ} \mathrm{C}, \quad$ w zakresie obciążenia $F=0 \div 20 \mathrm{kN}$ i prędkości $\varepsilon_{m}=10^{-3} \cdot \mathrm{s}^{-1}$. W próbie rozciągania użyte zostały okrągłe próbki wykonane równolegle do kierunku walcowania. Kształt i wymiary próbek określone zostały według wymagań normy EN 10002-1.

Reprezentatywne krzywe badanych materiałów wyznaczone na podstawie przeprowadzonych statycznych prób rozciągania. Kształty otrzymanych krzywych materiałów wysokowytrzymałych są typowe dla materiałów umocnionych. Ze względu na strukturę oraz własności mechaniczne badanych materiałów - w stanie dostarczenia nie wykazują one wyraźnej granicy plastyczności. Statyczna próba rozciągania jest 
Zeszyty Naukowe

Quality. Production. Improvement

podstawowym źródłem informacji o mechanicznych własnościach badanych materiałów, które przedstawia tablica 2 .

Do analizy mikrostruktur badanych stali wykorzystano mikroskop optyczny Axio Imager A1m. Obserwacje prowadzono przy powiększeniach w zakresie $25 \div 2000$ razy. Rejestracja obrazów mikrostruktur wykonana została, sprzężoną z mikroskopem, kamerą cyfrową AxioCam MRc5 z wykorzystaniem oprogramowania AxioVision SE64Rel.4.8. Obserwacje próbek stali wysokowytrzymałej Domex 700MC przedstawiono na rys. 2., 13.

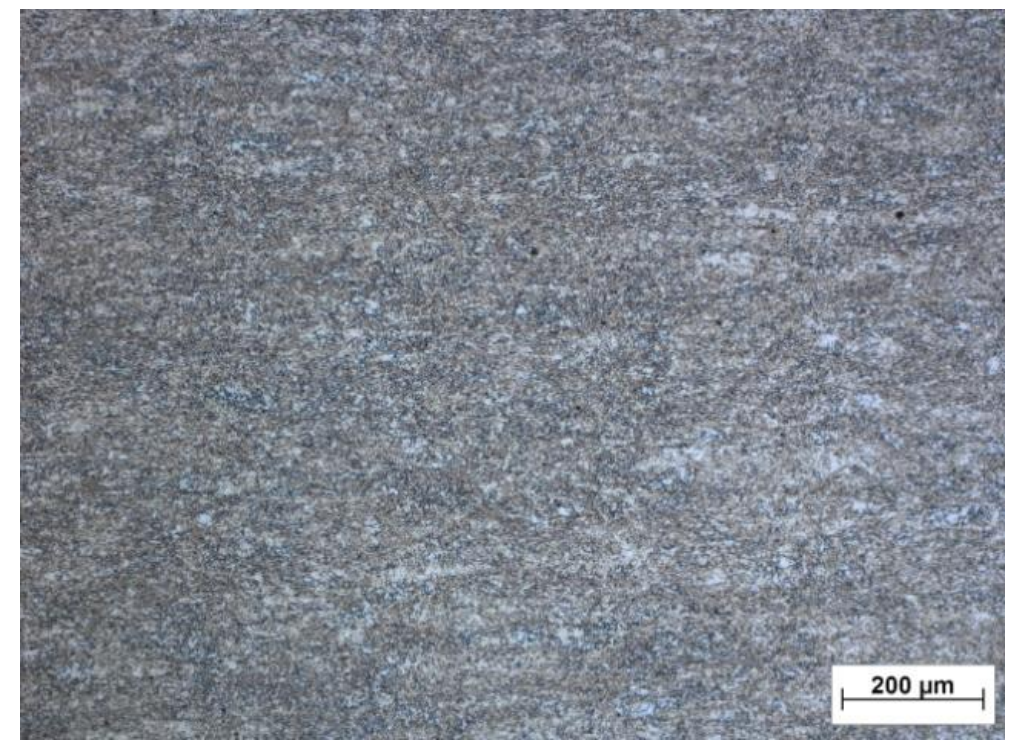

Rys. 2. Mikrostruktura stali Domex 700MC w stanie dostarczenia, po trawieniu 1-procentowym Nitalem

Źródto: opracowanie własne 


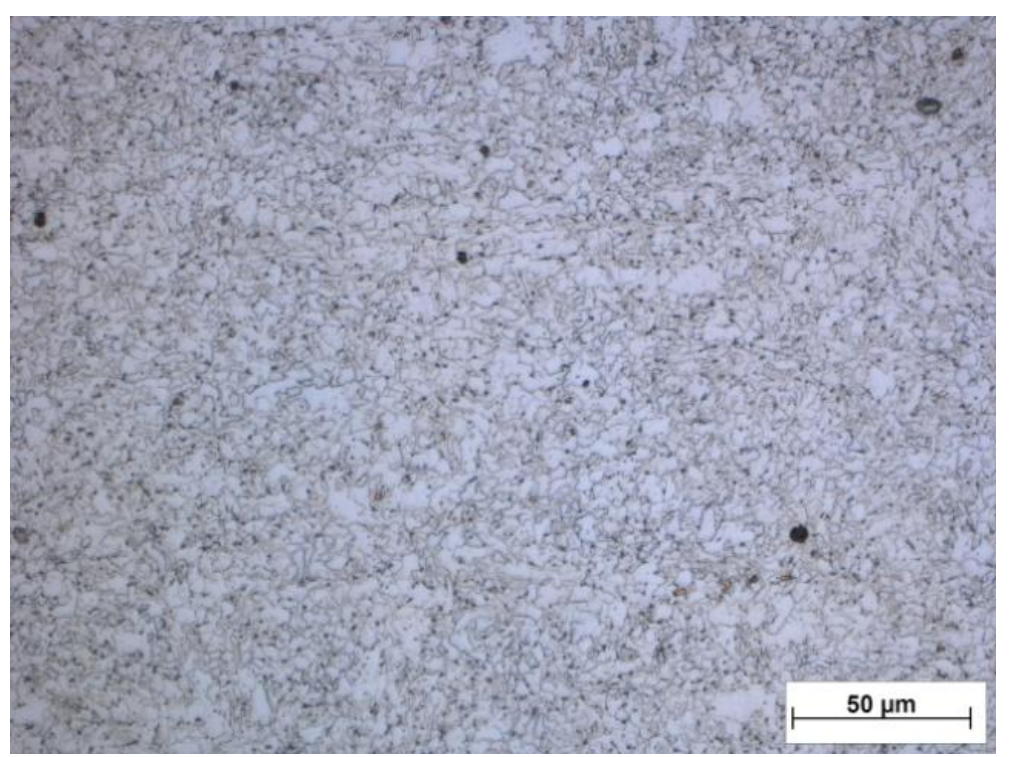

Rys. 13. Mikrostruktura stali Domex 700MC w stanie dostarczenia, po trawieniu 1-procentowym Nitalem, powiększony fragment rys. 2

Źródto: opracowanie własne

Stal Domex 700MC charakteryzuje się strukturą drobnoziarnistą. Zaprezentowany obraz mikrostruktury uwidocznił sporadycznie występujące cząstki azotku tytanu, o regularnym geometrycznym kształcie, koloru pomarańczowego. Materiał badawczy charakteryzuje również występowanie nielicznych inkluzji, w postaci czarnych cząstek sulfidów MnS.

\section{Badania odporności na zlamania udarowe}

Dla określenia właściwości charakteryzujących zachowanie się materiału w przypadku wystąpienia nagłych zmian obciążenia przygotowane zostały badania udarności analizowanych materiałów. Testy wykonane zostały dla czterech materiałów badawczych w zakresie temperaturowym od $-70^{\circ} \mathrm{C}$ do $+100^{\circ} \mathrm{C}$. W tym celu wykorzystano 
wyposażenie laboratorium, pozostawiając na założony czas próbki w piecu/zamrażarce, aż do osiągnięcia założonej temperatury w całych objętościach próbek. Próbie udarności poddano 20 próbek, kształt i wymiary próbek wykonanych według PN-EN 10045-1 przedstawiono na rys. 4.

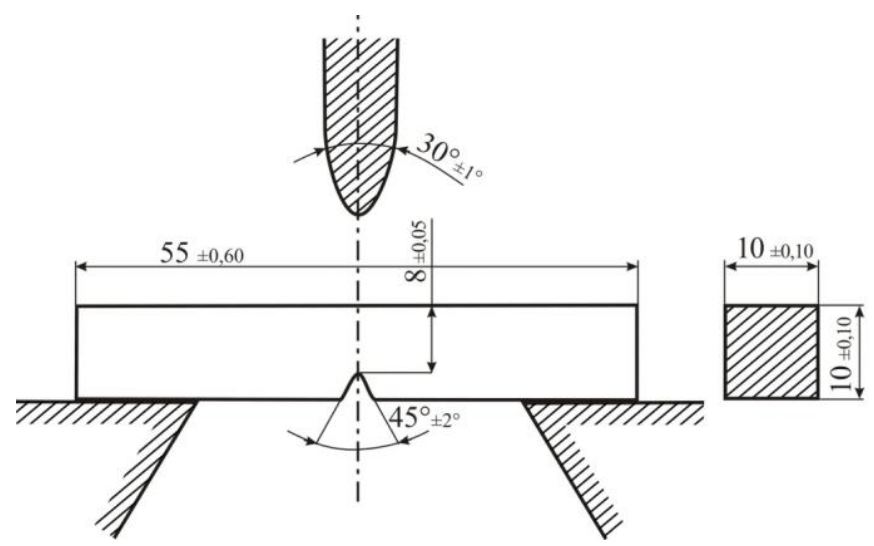

Rys.4. Kszatalt i wymiary próbki stosowanej w badaniach udarności

Źródto: opracowanie własne

Zastosowane zostały standardowe próbki typu Charpy, o długości 55 $\mathrm{mm}$ i przekroju poprzecznym kwadratowym o boku $10 \mathrm{~mm}$. W połowie długości próbki wykonany został karb w kształcie litery $\mathrm{V}$ o kącie $45^{\circ}$, głębokości $2 \mathrm{~mm}$ i promieniu zaokrąglenia jego dna $0,25 \mathrm{~mm}$. W wykonywaniu prób udarnościowych wykorzystano młot wahadłowy Charpy'ego o nominalnej energii $300 \mathrm{~J}$, w temperaturze otoczenia do $22^{\circ} \mathrm{C}$. Próby udarnościowe przeprowadzone były zgodnie z normą EN 10045-2, na zasadzie przebijania pojedynczym uderzeniem młota wahadłowego próbki z centralnym nacięciem $\mathrm{V}$ i podpartej na końcach. Do preparatyki próbek wykorzystano blachy materiałów badawczych w stanie dostarczenia. $Z$ otrzymanych wyników przeprowadzonych badań scharakteryzowano pracę łamania, a następnie wyznaczono krzywą przejścia plastyczno-kruchego. Badania udarności materiałów objęły również analizę morfologii powierzchni złamania próbek dla określenia 
temperatury kruchości stali. Analiza zmian udziału pęknięcia kruchego na obrazach makroskopowych badanych przełomów przedstawione zostały na rys. 5 .

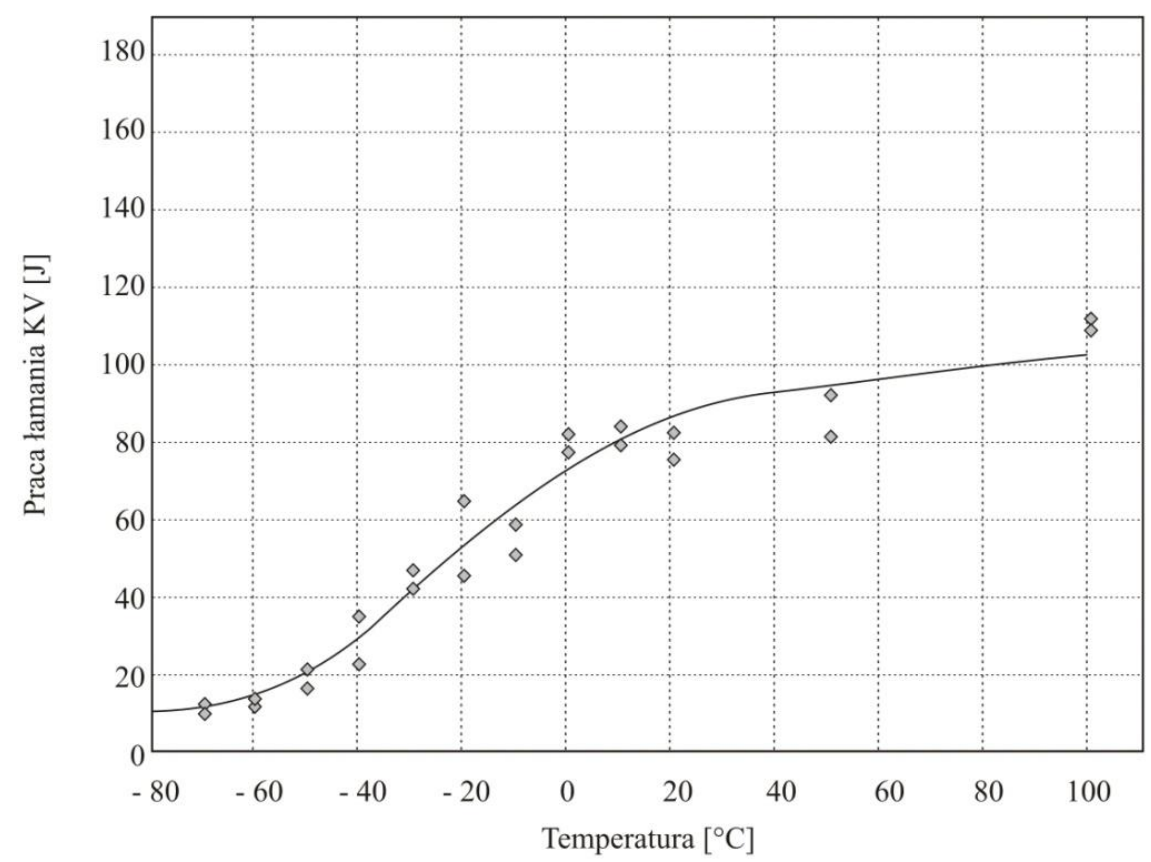

Rys. 5. Krzywa przejścia plastyczno-kruchego stali Domex 700MC

Źródto: opracowanie własne

Przejście w stan pękania kruchego dla badań stali Domex 700MC określono na poziomie temperatury $-20^{\circ} \mathrm{C}$. Poniżej tej temperatury udział pęknięcia kruchego wyniósł już ponad $65 \%$, aż do $84 \%$ w temperaturze $100^{\circ} \mathrm{C}$ (rys.6). Analiza wszystkich przełomów próbek powyżej $0^{\circ} \mathrm{C}$ wykazała występowanie podłużnych pęknięć w zakresie kruchego mechanizmu pękania, co wskazuje na kierunek walcowania materiału. 
Zeszyty Naukowe

$\operatorname{Nr} 1(4)$

Quality. Production. Improvement

a)

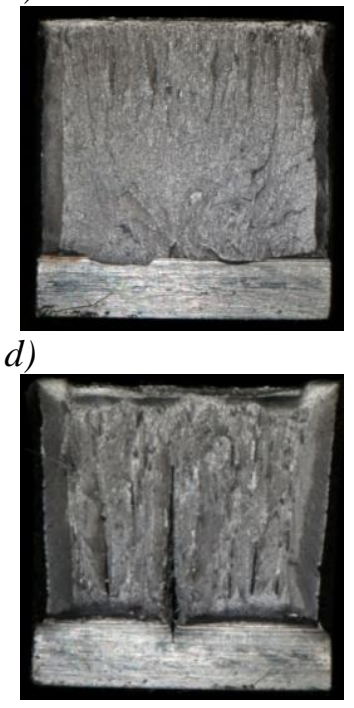

g)

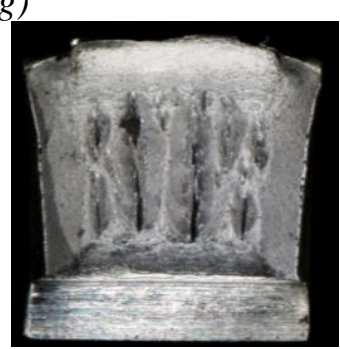

b)

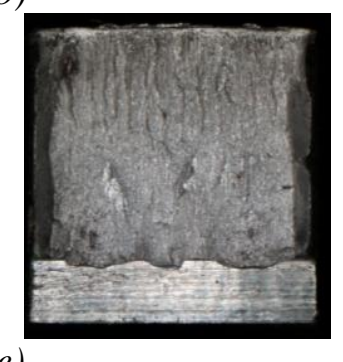

e)

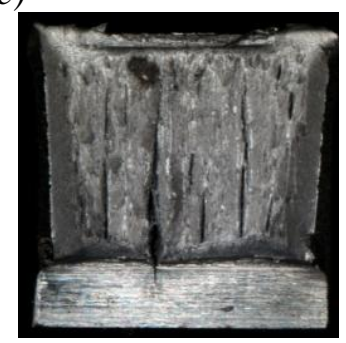

h)

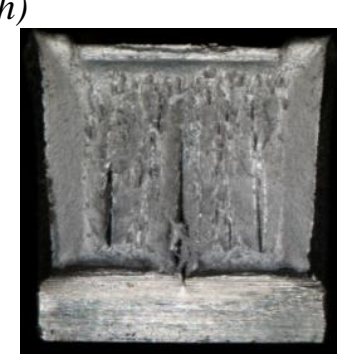

c)
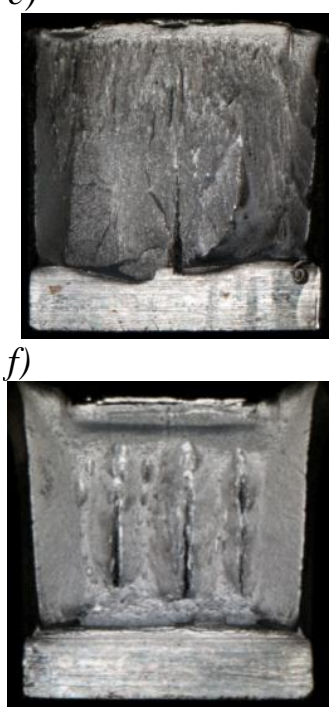

Rys.6. Makroskopowy obraz przelomów żamanych próbek stali Domex 700MC w temperaturze: a) $\left.\left.-100^{\circ} \mathrm{C}, \mathrm{b}\right)-60^{\circ} \mathrm{C}, \mathrm{c}\right)-30^{\circ} \mathrm{C}$, d) $\left.\left.0^{\circ} \mathrm{C}, \mathrm{e}\right)+10^{\circ} \mathrm{C}, \mathrm{f}\right)+20^{\circ} \mathrm{C}$, g) $\left.+50^{\circ} \mathrm{C}, \mathrm{h}\right)+100^{\circ} \mathrm{C}$

Źródto: opracowanie własne

\section{Podsumowanie}

Coraz większego znaczenia nabierają badania w zakresie badań zmęczeniowych wysoko- i ultrawysokocyklowych, biorąc pod uwagę 
zwiększoną eksploatację konstruowanych maszyn i urządzeń, jak również wydłużony czas użytkowania. Badania wytrzymałościowe stali wysokowytrzymałych potwierdziły ich wysokie własności deklarowane przez producenta. Nowe naczepy serii Master wytwarzane przez firmę WIELTON S.A. reprezentują nowe kierunki rozwoju firmy. Jednym z głównych elementów rozwoju firmy jest stworzenie nowych „lżejszych” od poprzedników naczep samowyładowczych. Możliwości obniżenia masy całkowitej naczepy konstruktorzy oparli na zmianach kształtu konstrukcji oraz zastosowaniu nowych materiałów. Możliwości zastosowania badanych materiałów w konstrukcjach naczep samochodowych produkowanych przez firmę WIELTON S.A. przedstawiono na rys. 7 .

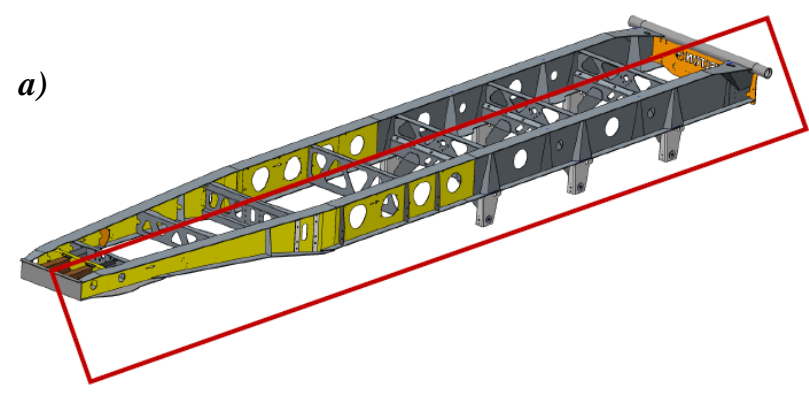

b)

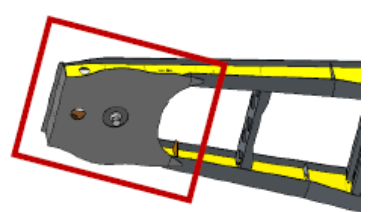

c)

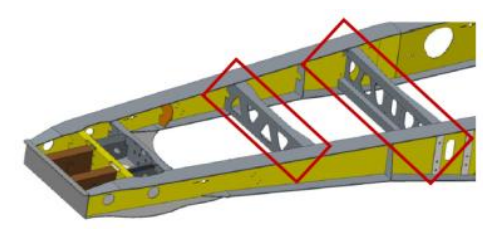

Rys. 7. Przykłady możliwości zastosowania stali Domex 700MC w konstrukcjach elementów podwozia naczep firmy WIELTON S.A.: a) podtuznice ram, b) plyta podsiodtowa, c) belki poprzeczne ramy

Źródto: opracowanie na podstawie danych producenta 
Stal Domex 700MC może być zastosowana do wykonania wielu elementów podwozia naczep samowyładowczych, podstawowym wymaganiem w stosunku do tego materiału w pierwszej kolejności jest dobra spawalność. Granica plastyczności tego materiału dla konstrukcji podłużnicy ramy podwozia nie może być mniejsza niż $600 \mathrm{MPa}$, przy wytrzymałości na rozciąganie powyżej $700 \mathrm{MPa}$. W przypadku elementu płyty podsiodłowej wymagania te kształtują się na poziomie $R_{e} \geq 580 \mathrm{MPa}$, oraz $R_{m} \geq 650 \mathrm{MPa}$, a belek poprzecznych ramy $R_{e} \geq 540 \mathrm{MPa}$ oraz $R_{m} \geq 650 \mathrm{MPa}$.

Najważniejszymi parametrami dla konstruktorów naczep jest dopuszczalna masa całkowita (DMC) pojazdu, która bezpośrednio wynika z nośności wszystkich elementów i podzespołów wchodzących w skład pojazdu. Zgodnie $\mathrm{z}$ obowiązującymi przepisami dopuszczalna masa całkowita naczepy według wymagań drogowych nie może przekraczać $36000 \mathrm{~kg}$, dlatego też wielkość ładunku, który można załadować na naczepę, zależy od masy własnej samego pojazdu. Obniżenie masy własnej nowej serii naczep samowyładowczych sięga poziomu $10 \%$, co było możliwe zarówno dzięki zmianom konstrukcyjnym ramy nośnej, jak i zastosowaniu nowych materiałów. Celem firmy jest obniżenie masy o kolejne $20 \%$. W tym celu konieczna jest kompleksowa wiedza na temat nowych materiałów, w tym wiedza na temat własności zmęczeniowych.

\section{LITERATURA}

1. FlaXa V., Shaw J.: Material application in ULSAB-AVC, "Steel Grips", Vol. 1, No. 4, 2003, s. 255-261.

2. GRAJCAR A.: Struktura Stali C-Mn-Si-Al ksztaltowana z udziałem przemiany martenzytycznej indukowanej odksztatceniem plastycznym, Wydawnictwo Politechniki Śląskiej, Gliwice 2009.

3. Armigliato A.: Light Weighting in Commercial Transport, Conference "Connecting Innovations. Wielton", Warsaw 3-4 June 2014.

4. SSAB Oxelösund. 2012. The Steel Book. SSAB Communications. 2012 dane producenta. 
Zeszyty Naukowe

Quality. Production. Improvement

5. MAZUR M., UlewiCz R.: Fatigue Testing Structural Steel as a Factor of Safety of Technical Facilities Maintenance. Chapter 11, [w:] Quality of Materials, Monography, Borkowski S., Klimecka-Tatar D. (Ed.), Oficyna Wydawnicza Stowarzyszenia Menedżerów Jakości i Produkcji (SMJiP), Częstochowa 2012. 